\title{
article CRITICISM Of THE MEDIA IN HYPERMEDIA NARRATIVES
}

Copyright (c) 2010 SBPJor / Sociedade Brasileira de Pesquisa em Jornalismo
JOSÉ LUIZ AIDAR PRADO

Pontifical Catholic University of São Paulo
ABSTRACT

Based on our surveys in recent years of media narratives, which led to the construction of two hypermedia, one still in its final stages, in this article we shall develop the following themes: a) how to analyze and expose criticism of media narratives; b) what transversal perspectives with other disciplines were and are necessary to establish themes in contemporary journalistic narratives? Specifically, we present the role of political philosophy in Badiou and the sociology of absences in Boaventura Santos, among other authors; c) the methods adopted for the analysis of communication media contracts, which rule the post-modern narratives of magazine journalism. Our ultimate goal leads to epistemological and methodological debates, which are necessary for what this research faces in terms of "education for media".

Key-words: journalism studies, discourse and narrative, political philosophy, sociology of absences.

\section{JOURNALISTIC NARRATIVES AND MULTIFOCAL ANALYSES}

In this article we will examine research on journalism narratives aimed at education for media. For that purpose, I will introduce the activities we have developed in recent years in the Research Group on Printed Media, Umdiasetedias, at PUC-SP. Based on theories of discourse and communication as well as on sociological and philosophical theories, we built two multimedia databases on weekly and segmented magazines that offer navigation in hypermedia. Throughout these activities aimed at the study of jour-nalistic narratives, we prioritized education for media according to a multifocal ap-proach. We will explain in this article what this means.

From a semiotic perspective, narratives are successions in time of functions in which characters perform actions, resulting in a change of state'. In journalism, since the ' 60 s and ' 70 s, narratives have increasingly been integrating audio-verbal-visual characteris-tics, incorporating a syncretism of verbal texts, static images and video. Even when the support is printed, the texts are similar to those of Internet sites, although 
they do not carry videos and animations. When the support is electronic, audio-visual narratives can be done as on television, or in narratives with multimedia structure that can be navi-gated in hypermedia, such as on the Internet or on DVDs. Those are texts on hyper-spectacle in hypercapitalism, primarily addressed to consumption values of happiness (see SALECL, 2005) and success (see Prado, 2008).

As we were building an investigation into segmented magazines (feminine, masculine, youth, black, executive, well-being and homosexual) in the Umdiasetedias Research Group in Print Media (PUCSP), we carried out a multifocal reading of media head-lines, avoiding the construction of a one-sided discourse analysis produced by a known discourse analyst considered omniscient (see Bairon and PRADO, 2007). Instead of postulating a one-sided verbal discourse analysis, we developed a cognitive platform in which the database holds a variety of multimedia objects. We invited dozens of re-searchers, professionals and active members of civil society to participate in debates and interviews produced in films in order to create diverse discourse focuses on magazine communicative contracts (see CHARAUDEAU, 2006) with narratives developed from both figurative and thematic construction on referred issues. The project has a critical-activist attitude since the focus is on the construction of hegemonic media critique, where there is a predominance of monolingualism:

"This struggle can be defined as the clash between multilingualism and mono-lingualism. According to Bakhtin, the different creation of utterance agencies is moved by social and political forces that seek polyphony and the creation of new semantic possibilities, which he calls "multilingualism". On the contrary, the practices of information and communication are formed by forces that seek to standardize, centralize, homogenize, destroy the multiplicity and heterogene-ity of speech, language, semiotics, a process he calls "monolingualism". (...) And how do the forces that lead to monolingualism manifest themselves? Through the production of linguistic norms. Well, the linguistic rules are not an abstract imperative; they are not only repressive. They are the creative forces of the life of a language, but a unified language." (LAZZARATO, 2006, p.158).

Linguistic norms tend to build up under a regime of visibility and voices separating The Same and The Other, namely, those established from common cultural imaginary con-structions and outsiders, who are represented as tolerated, excluded, rendered invisible or stigmatized (see ELIAS, 2000 and PRADO, 2008a). The fantasies of the middle classes organize these imaginary constructions of the Same and the 
Other that appear in magazine communication contracts. The contract establishes an addressor and an ad-dressee in the text, who are nothing more than projections - the company's and journal-ists' collective constructions directed to the consumption of the publication and the products and services directly or indirectly advertised in the articles and advertisements. The addressee is the reader projected in the text from results of polls held in focus groups commissioned by the publishing company².

In practice, the investigation of these contracts with their respective narratives full of processes related to the production of figures and themes led to the construction of a multimedia bank in order to build a viable support in which the critical narratives about the journalistic narratives could support these multi-focused approaches ${ }^{3}$. What does multi-focused approach mean? It means exactly the need to restore multilingualism in the narratives in which monolingualism prevails as described by Lazzarato (idem), im-plied by the existence of strong, wise enunciators who establish the rules and scientific norms of behavior. That was the direction in which we chose to build the hypermedia, featuring an understanding of multiple perspectives for education regarding media. Hy-permedia is a

"permutational, combinatorial and interactive form of multimedia, in which text, sounds and images (still and moving) are interconnected by probabilistic and moving links, which can be set up by receivers in different ways so as to com-pose unstable works in infinite quantities" (Machado in Domingues, 1999, p.146).

Such discussions also have a corollary that, despite not being studied in this text, would deserve later development, namely, how this organization of data and information in multimedia databases prepared according to their interfaces would apply. This organi-zation that enables navigation in hypermedia could be used by journalists in their own writing, offering readers the chance to access the contents worked historically, such as, for example, the synthesis of a war or a crisis in which the journalist can provide not only information on a single day, but rather make a historical approach in a specified period of time. This would require journalists to be well trained in other disciplines, such as history, sociology, anthropology etc., or the combination of a multidisciplinary group of professionals when writing. This new model would change the format and con-tent of news and stories. It would not be the case of simply using verbal content sup-plemented by video 
attachments, but rather the arranging of multimedia content to make verbal and visual texts closely interconnected.

\section{Theme tree}

In terms of discourse analysis, the project builds a thematic tree comprising the journalistic framing of reports ${ }^{4}$, consisting of tags (or key words) related to the paradigm of identifying with characters who are successful in their sexual, love and professional life models based on individualistic values, emphasizing a bio-political approach to body transformation for health, quality of life and a certain ideal of happiness (which have a common core, but vary in terms of consumption values in each type of magazine). The motto of those cognitive maps offered by enunciators includes discourses that aim at inviting media narrative responses to answer the question: "Who am I to myself? Ac-cording to women's magazines, a woman must be authentic and she must be better. This transformation point moves a market of products and services (beauty, hygiene, food, drugs etc.) supported by technologists working in various areas of speech, which stan-dardize packages of language modalities (meet $\mathrm{T}$, be like $\mathrm{X}$, do $\mathrm{Y}$, choose $\mathrm{Z}$ ) for people who want to be different, characterizing an identity cul-de-sac: everyone has to be dif-ferent and the enunciators offer uniform, targeted packages in each niche. In those maps and recipes enunciators must use the imperative modality, often marked by kindness and friendliness: "dear friend, we are close to you, we know your needs and desires, we do research, we listen to the experts and scientists and it is all summarized in story XX".

Ultimately, what matters is that the subject engages in the recommended experience and chooses his way to pleasure, supported by his consumption values, advised and directed by knowledgeable multiple media enunciators. The enunciator promises the addressee: "You have huge power" (SALECL, 2005, p. 25). It is a paradoxical position, because the addressee is depicted as someone dependent on a sequence of knowledge while con-sidering the need to choose and act. It is not a event path in the sense proposed by Badiou because the addressee can do anything except call into question the capitalist way of life, the individualistic way to success. Enjoy (life) freely, but remain within the hyper-spectacle of hyper-capitalism in which semiotic overproduction prevails (DURÃO, 2008, p. 39).

\section{The hypermedia narrative and the abysmal line}

The first question that arises in relation to information architecture 
design is how to make the variety of multimedia objects available to the hypermedia user. How to orga-nize them in interfaces in order to achieve the research goal? Then, how to conceive the interfaces so as to explore the hypermedia potential of multimedia database more efficiently? A necessary game arises at this point, considering the objectives of education before media, between the function designed for informing from the database, and the function of organizing the critique of media texts, using multimedia and hypertext re-sources. Informing in this case is not the same task as it is for print media, in which in-formation is selected from the scheduling of facts, focused on the awakening of the con-sumer's attention. It is a matter of choosing a number of media texts about a specific topic and submitting them to the critical and proactive reading of many individuals so as to build multiple readings of stories. We shall discuss each one of these topics:

a) What kind of information will be offered to the addressee and how will it be orga-nized?

b) How will multimedia objects be articulated in the information architecture and inter-faces? This articulation should involve verbal texts, magazine images and videos so as to fully develop the potential of multimedia research.

c) How can navigability be formulated from a hypertext-oriented approach?

d) How can the aesthetic-informational project of interfaces be built to attain the goals previously mentioned?

e) How can the users' skills be developed in their relationship with the database? What skills are projected by hypermedia for its addressee?

f) What kinds of learning experiences are meant to be created with navigation? What does educating to cope with media mean?

g) What kind of knowledge about the world of cognitive capitalism (related to semiotic overproduction, hyper-capitalism) must be added to hypermedia in order to contextual-ize the process of criticism of media devices? How can this be done from the corpus of the journals studied, that is, from verbal-visual journalism narratives?

We shall discuss each one of these items. Firstly, what kind of information will be of-fered to the hypermedia addressees? It is not a question of enabling them to learn the language of the media or to write texts for magazines. It is a matter of building experi-ence based on video interviews and on analytical discussions of hypertexts so as to cre-ate the phenomenological perception of a multiplicity of readings and critical ap-proaches. This is what multi-focal oriented approaches means. 
Boaventura Santos (2010, p. 31) qualifies modern thinking as abysmal because it estab-lishes two sides of knowledge: the visible one, such as knowledge of science and tech-nology, and the invisible one, such as everyday, practical knowledge. The latter is made visible only if necessary to be explored, as for example, the indigenous knowledge about the Amazon rainforest biodiversity.

"At the other end of the line there is no actual knowledge, there are beliefs, opin-ions, magic, idolatry, intuitive or subjective understandings, which, at best, can become subjects or raw material for scientific inquiry" (Santos, 2010, p.34).

On one side of the abysmal line is marital status; on the other, the state of nature that existed in colonial days. The hegemonic view does not see the relationship that connects one to the other side of the abysmal line, but rather, the violent otherness that must be exterminated or civilized. There lies the territory that belongs to the Other, to the cannibal, to Coetzee's barbarian (2006), which threatens and frightens us with the possibility of being invaded. Thus, in the colony, says Santos, the game between systemic regula-tion and emancipation did not prevail; the game between appropriation and violence triumphed. According to the logic of the abysmal, the Same crosses the line to conquer the territory of the Other, the uncivilized. It does so by means of appropriation, which involves "incorporation, cooptation and assimilation, whereas violence implies physical, material, cultural and human destruction" (ibid, p.38) ${ }^{5}$.

For Santos, although there are no longer settlements and cities in the modern sense, there is still the abysmal line that "divides the human from the sub-human world" (ibid, p.39):

"Today, Guantanamo represents one of the most grotesque manifestations of ab-ysmal legal thought, the creation of the other side of the fracture as a non-territory in legal and political terms, an unimaginable space for the rule of law, human rights and democracy. But it would be a mistake to consider it an excep-tion. There are many Guantanamos, from Iraq to Palestine and Darfur. More than that, there are millions of Guantanamos in sexual and racial discrimination in both public and private spheres, in the wild areas of megacities, in the ghettos, in sweatshops, in prisons, in the new forms of slavery, trafficking of human organs, in child labor and exploitation of prostitution "(ibid, p. 39).

This way of examining the symbolic game between the Same and the Other in the era of global capitalism interacts with that of Agamben 
(2002), who depicts homo sacer as the creature who is only worth his "bare life," that is, his biological life, unsupported by symbolic ordering. Therefore, what is decisive in modern politics

"is the fact that alongside the process by which the exception becomes the rule everywhere, the space of bare life, originally located at the margin of ordering, gradually comes to coincide with the political space, and exclusion and inclu-sion, external and internal, bios and zoé, law and fact, enter a zone of irreducible indistinctness. The state of exception, in which bare life was simultaneously ex-cluded and captured by ordering, in the distance between them, it was actually the hidden foundation on which the entire political system rested; when its bor-ders becloud and lose determination, bare life that inhabited it gains freedom in the city and becomes concurrently subject and object of political ordering and its conflicts, the common point of both the organization of state power and the emancipation of it. Everything happens as if, at the same rate of the disciplinary process through which state power makes living man a specific object, another process advanced which roughly coincides with the birth of modern democracy, in which living man emerges not as an object but as a subject of political power. In many ways these processes are opposing and (at least in appearance) in bitter conflict between one another; they converge, however, in the fact that what is in question is the bare life of the citizen, the new bio-political body of humanity" (AGAMBEN, 2002, p.17).

\section{Sacer}

Homo sacer ${ }^{6}$ is not just the sans-papier, a prisoner at Guantanamo, in Palestine, but all those who are sought by the providers of humanitarian aid. If on one side we have that Other whose only worth is its bare life, on this side of the abysmal line we also have in action the bio-politics that summons the members of the Same world to fit their identity in cultural niches, where life is developed by brands, with homogeneous styles and class symbols. Along the same path, members of the Same would also fit their identity in the market niches and services necessary for the construction of the appropriate body that suits the membership, which covers it with the signature clothing of such cognitive capitalism. (PRADO, 2006 and 2010, DURÃO, 2008). The media, marketing, scientific and publicity devices feed those convening systems with information and new products incorporated into adapting packages ignited by slogans (PRADO, 2010, p.63). The hegemonic communication mode makes the hegemonic narratives describing new find-ings about the improvements of suitability and body appear to respond to on demand appeal of consumers, who are agile and eager to learn. Interactivity is the name of this appearance in the era of hyper-spectacle. 
Hypermedia examines these bio-political narratives of media devices, in which commu-nication contracts offer addressees adaptations for continuous construction and recon-struction of their bodies so as not to become people with no ties, no connections, des-tined for the trash can, as Bauman (2007, p.7) states. These adaptations suggest proce-dures for success, wealth and related values to the Same, such as youth, beauty, eroti-cism and sociability.

From the readings of a wide range of objects in the database, properly organized accord-ing to navigation criteria (hypermedia), we intend to produce a balance of similarities and differences of discursive constructions of the magazines in relation to such bio-political maps. Therefore, the user will have greater ability and critical competence to read magazines comparatively, examining the regimes of visibility and invisibility of the media. It is necessary to recognize different enunciators: those who enthusiastically seek to present the success of many social discursive positions, the friends of the woman reader who try to come too close as they offer advice, the sober wise ones sup-ported by the discourse of science, the knowledgeable multicultural professionals who are acquainted with variegated niches. They are joined by different addressees projected by the text: one who seeks guidance for his life; one who wants to identify with a tough, conservative, closed speech; one who pursues information in order to take a position based on one's own experience; one who aspires to milder, positions, green-oriented ones etc.

\section{Deconstructing Loyalty}

From this perspective, the experience involving multiple readings of magazines is cre-ated, showing the convening of media in the various groups of magazines (female, male, etc., as already mentioned). What are the thematic schedules for the cover and for the internal part of the magazine? What characters among men, women, homosexuals etc. materialize these bio-political choices of themes? What values are developed from these communication contracts offered by multiple enunciators, linked to the renewal of life and its transformation ceaselessly postulated on consumption values? What kaleido-scope of successes is offered through the convening of speakers?

The requirement for the construction of this multi- and hypermedia narrative is that navigation triggers a multi-perspective of journalistic narratives, after numerous voices are heard following examination of the magazines, after images of those thematic and figurative media constructions are viewed and after the hypertexts analyses are read. The 
crossover of the analyses of contracts for various groups of magazines also allows a comparison of media strategies, indicating similarities and differences, enabling, there-after, a critical confrontation of media texts.

Placing readers - - faithful to few media devices in general - in contact with numer-ous experiential perspectives should, in principle, bring about a first consequence: de-construct their loyalty, making them more inquisitive about the enunciators to whom they have been loyal. It is a matter of knowing what a hegemonic device is by means of an experience in which we do not suppose a critical deconstructive unit, built from the critic's enunciation role, but rather developed from multiple perspectives, distributed in the speeches of various critical positions: the activist's, the deconstructive text re-searcher's, the critical journalist's etc. At the end, the hypermedia narrative indirectly questions its user: what does it mean to construct narratives about journalistic success, about health, about wealth, in segmented magazines? As that success is specific to the Same's imaginary, linked to middle class consumption, in which otherness is it circum-scribed so that the Other does not have a voice or has his voice and his image made in-visible or reduced from specific fantasies? The variety of critical positions deconstructs uncritical positions of cognitive maps featured by the magazines' hegemonic enuncia-tors.

In this movement towards multi-perspectives of the hypermedia enunciator's critical force lies our wager against a univocal master-disciple relationship, not only against a formalistic methodology that obscures the reality of the discovery, but also against the cynicism of those who consider hyper-spectacle fun and expect the lack of commitment of the network market.

Users must deconstruct loyalty, but not at the cost of enslaving themselves to a new enunciator. In fact, deconstructing loyalty is to manage to accomplish something like an opening, an incision in a school learning background, which is not only cognitive, but also behavioral, existential, and instinctual. As Bachelard said, "Society truly ruins the child's brain; it annihilates language, education and training" (apud QUILLET Bache-lard, 1977, p.16). Educating for media here means to mis-educate, to mis-train, to disconnect viewers from their symbiotic relationship with the univocal bio-political enunciator. Spectators are intelligent, but they are immersed in a market-stricken culture melting pot, in which a sociology of absences is required to show other possible ar-rangements for the visible (SANTOS, 2010). Educating means, first, to expose the hegemonic so as to be able to see other ways of knowing and 
experiencing the world and devices (AGAMBEN, 2009; FOUCAULT, 2007; PRADO, 2010).

\section{Navigation Filters}

So instead of presenting the hypermedia narrative through centralizing hypertexts, we shall try to provide the hypermedia with ways to carry out searches by offering several filter organizers for the multimedia objects. Therefore, the interfaces will consist of search enablers: the users will be able to apply thematic markers to bring in all subjects and choose whether they want to examine images of magazines at first, or interview videos or descriptive-analytical texts. They will also be able to bring in all the subjects in ascending order of complexity: those related to the magazine descriptive modules, those related to groups of magazine, cross-checking the groups or, eventually, choosing the theoretical module, in which discussions are made deeper and contextualized in me-dia culture of a globalized world.

Thus, the search can derive from demands in order to arrange subjects to be chosen ac-cording to a variety of criteria:

a) search by unit: users search for their subjects from a thematic marker, a magazine or a group (e.g. I browse for all subjects related to the theme beauty and fashion or for anything about the Claudia magazine)

b) double searches: users request the interface to bring them all subjects related: to a topic and a group, to a topic and a magazine, to a marker and a group, or to a thematic marker and a magazine (for example, choosing a marker about sexuality, such as "pleasure" and Men's health magazine and find out what subjects are related to that in-tersection)

c) search for the image of the magazine (a list would be available here)

d) search for the interview videos (idem, by the name of the interviewee)

In addition, there are entries for:

a) theoretical module (conceptualization, discourse, publicity, biopolitics, celebrities, experience)

b) general introduction and explanation about the dvd

c) entries

The searches will reveal the possible relations between scattered subjects on the screen. Clicking on any search, no matter if is unitary, double, by image or by interviewee, the program brings together all 
the subjects gathered by that relationship. Two topics can actually be brought closer. To make this possible, the database contains a record of each subject with four topic markers. This record is also linked to the modules to which it relates. When the selection is made by demand criteria, there is a dividing line that iso-lates topics on part of the screen. For example, a background frame may pop up to show them, and the users can click on each topic. Users can choose to view only the videos, before the hypertexts. In each case the appearance will be different:

- In a unit research by topic or by markers, all the subjects (videos, hypertexts and im-ages) will appear. Each type will be displayed in a different color and possibly in a dif-ferent way. In order to choose one of them, the user must click on the browser icon. The characterization will appear as the mouse rolls over it.

- In a double search, the crossover of topic and group, for example, all the related sub-jects will appear.

- In the others, the same kind of subject will always appear: either just videos or images only.

\section{Event as mis-education}

Understanding this project as education in relation to media, the author intends to offer a view of contemporary media, considering that not every inhabitant of the hyper-spectacle city is cynical or uninterested in politics understood as events, a term developed by Badiou (2009).

For Badiou, contemporary democratic materialism counts on the existence of the body full of jouissance from the viewpoint of a marketoriented pragmatic approach projected on hyper-spectacle screens, incensed by the new simulacra of theoreticians on duty; the fantasy that "man, under the sway of the 'power of life,' is an animal convinced that the law of the body nourishes the secret of his hope "(BADIOU, 2009a, p.2). From this per-spective current materialism

"is the materialism of life. It is a bio-materialism. Above all, it is essentially a democratic materialism because by recognizing the plurality of languages, the contemporary consensus presupposes its legal equity. So, humanity's assimila-tion to animality culminates at the identification of the human animal with the diversity of its sub-species and democratic rights inherent in this diversity "(ibid.).

The events put into play by Badiou are precisely what the supporters of hyper-capitalism think no longer exist, as they watch the scene from their 3D hyper-immersive screens. A event is exactly that which "does 
not follow the immediate law of things" (Badiou, 2009, p.32), that is, that which does not simply remain in search of the "free virtualities of the body" (BADIOU, 2009a, p.507), but rather gambles on what the life of the immortal man can become when he moves away from survival within the cognitive maps of hyper-spectacle, i.e. the order of the world as it is. Man would thus inaugurate a new collective subject in science, art, politics or love (ibid.). This is the "birth of a world in the flash of the instant of appearing, to which he belonged previ-ously in an extinct manner, tracing the world and signaling toward life" (ibid.).

\section{NOTES}

1 Regarding this theme, also see MOTTA, 2004 and PRADO 2007.

2 To learn more about the fantasy concept, see ŽIŽEK (1997).

3 The magazine groups are: Feminine, Masculine, Youth, Executives, Well-being, Black, Homosexual. The main themes and markers are: Fashion and beauty, health and well-being, sociability and sexuality, and work, leisure, and tourism.

4 For the framing concept, see PORTO (no date).

5 For the construction of the imaginary of the Same and the Other in weekly magazines, see PRADO (2005, 2006, e 2008a).

6 Regarding homo sacer also see ŽlŽEK (2003, P.103).

\section{BIBLIOGRAPHY}

AGAMBEN, G. What is an apparatus. Stanford, SUP, 2009.

G. Homo Sacer. O poder soberano e a vida nua I. Belo Horizonte, UFMG, 2002.

BADIOU, A. Éloge de l'amour. Paris, Flammarion, 2009.

Logics of worlds. Being and event 2. New York, Continuum, 2009a.

BAUMAN, Z. Vida líquida. Rio de Janeiro, Zahar, 2007.

CHARAUDEAU, P. O discurso das mídias. São Paulo, Contexto, 2006.

COETZEE, J.M. À espera dos bárbaros. São Paulo, Cia das Letras, 2006.

DURÃO, F. A. A indústria cultural hoje. São Paulo, Boitempo, 2008. 
ELIAS, N., SCOTSON, J. Os estabelecidos e os outsiders. Rio de Janeiro, Zahar, 2000.

FOUCAULT, M. História da sexualidade. A vontade de saber. Vol.1. Rio de Janeiro, Graal, 2007.

LAZZARATO, M. As revoluções do capitalismo. Rio de Janeiro, Civilização Brasileira, 2006.

MACHADO, A. Hipermídia: o labirinto como metáfora. In: DOMINGUES, D. A arte no século XXI: a humanização das tecnologias. São Paulo, Unesp, 1999.

MOTTA, L.G. Narratologia. Análise da narrativa jornalística. Brasília, Casa das Musas, 2004.

PORTO, M. Enquadramentos da mídia e política. NEMP, mimeo, s/d.

PRADO, J.L.A. Convocação nas revistas e construção do 'a mais' nos dispositivos midiáticos. In: Matrizes. Ano 3, n.2, pg.63. São Paulo, ECA-USP/Paulus, 2010.

Programas cognitivos e passionalização do consumo nos media e na publicida-de. Comunicação, Mídia e Consumo, São Paulo, ESPM, v.5, pp.87-101, 2008.

(org.) A invenção do Mesmo e do Outro na mídia semanal, o DVD. São Paulo, PUC-SP, 2008a.

As narrativas do corpo saudável na era da grande Saúde. Contemporânea, v.5, 2007.

Regimes cognitivos e estésicos na era comunicacional: da invisibilidade de práticas à sociologia das ausências. Comunicação, Mídia e Consumo, São Paulo, ESPM, v.3, n.8, pp.11-32, 2006.

O leitor infiel diante dos mapas da mídia semanal performativa. Revista Fronteiras, São Leopoldo, v.VII, n.1, pp.39-46, 2005.

PRADO, J.L.A. e BAIRON, S. A invenção do Mesmo e do Outro na mídia semanal. In: BENETTI, M. e LAGO, C. Metodologia de pesquisa em jornalismo. Petrópolis, Vozes, 2007.

QUILLET, P. Introdução ao pensamento de Bachelard. Rio de Janeiro, Zahar, 1977.

SALECL, R. Sobre a felicidade. Ansiedade e consumo na era do hipercapitalismo. São Paulo, Alameda, 2005.

SANTOS, Boaventura S. (org.) Epistemologias do sul. São Paulo, Cortez, 2010.

ŽIŽEK, S. S. Bem-vindo ao deserto do real. São Paulo, Boitempo, 2003.

The Plague of fantasies. London, Verso, 1997. 
José Luiz Aidar Prado is a Professor Doctor at the Pontifical Catholic University of São Paulo (PUC-SP) Semiotic and Communi-cation Postgraduate Studies program, organizer of the hypermedia "The invention of the Same and the Other in weekly media" and coordinator of the Umdiasetedias Research Group for Printed Media (www.pucsp.br/pos/cos/Umdiasetedias). 